\title{
Factors Associated with Stunted Children
}

\author{
Bertakalswa Hermawati ${ }^{1}$, Oktia Woro Kasmini Handayani ${ }^{2}$, Dhevy Fajriyatul Umma ${ }^{3}$, \\ Adinda Yustika Seftiani ${ }^{4}$ \\ \{bertahermawati@gmail.com ${ }^{1}$,oktia_woro@yahoo.co.id ${ }^{2}$,dhevyfajriyatul14@gmail.com ${ }^{3}$ \}
}

Universitas Negeri Semarang, Semarang, Indonesia ${ }^{1,2,3}$

\begin{abstract}
Stunting is the high-priority problem of child malnutrition in Indonesia. The purpose of this study was to determine the relationship between maternal posture and exclusive breastfeeding and stunting. This research will be conducted with a quantitative approach. This study was designed with a cross-sectional study design. The population is parents of stunted children aged 3-5 years in Demak district, Central Java. The sampling technique used in this study was purposive sampling and the sample was 36 parents of stunted children aged 3-5 years in Demak district, Central Java. The research instrument was a questionnaire and test. Data analysis used the chi-square test to measure the association between maternal posture and exclusive breastfeeding and stunting. The results showed there was no relationship between stunting and maternal education (OR.0,7,95\% CI, 0,132-4,022;P=1.000), level of income (OR.0,7;95\% CI, 0,132$4,022 ; \mathrm{P}=1.000)$, maternal posture $(\mathrm{OR}, 1.0 ; 95 \% \mathrm{CI}, 0,320-3,123 ; \mathrm{P}=1.000)$, and exclusive breastfeeding (OR, 1,5;95\%CI,0,469-4,797;P=0,660).
\end{abstract}

Keywords: stunting, maternal education, level of income, maternal posture, exclusive breastfeeding.

\section{Introduction}

Stunting is a condition of children under five who have deficit height-for-age. It is measured by length or height with a z-score of less than -2SD / standard deviation (stunted) and less than -3SD (severely stunted) [1]. In 2014, 159 million children under 5 years of age in the world were stunted. More than half of early childhood in Asia are stunted (57\%) and in Africa $37 \%$ [2].

This condition has a long impact both individually and socially. These include poor thinking skills and achievement in later childhood and adulthood due to weaknesses in cognitive abilities, language skills, motor-sensory abilities, low productivity, slow physical development. Broadly, stunting has an impact on the country's economic growth constraints, increasing poverty and wealth inequality[3].

Indonesia is the 5th biggest stunting problem in the world. The prevalence of stunting of children under five in 2017 was $29.9 \%$ [4]. The findings also state that stunting occurs in households/families with various levels of social and economic welfare in Indonesia[5] Central Java is the 17th province in Indonesia with stunting cases with a prevalence of $28 \%$ [4]. Demak is the 5th region with high stunting cases in Central Java with a total of 50,782 cases. The data found the proper parenting and good nutritional intake are still not optimally implemented in these areas [6]. 
Several factors can cause stunting, including maternal posture (short), and exclusive breastfeeding during birth [7], and demographic factors such as maternal education and income level [8][9][10][11]. Research results have shown that someone who is born shortly posture is inherited by his mother [12]. Besides, other experts argue that the development of the baby is not optimal because the baby does not get exclusive breastfeeding for 24 months [9][13][14][15].

This study aims to determine a relationship between maternal education, income level, maternal posture, and exclusive breastfeeding for stunted children.

\section{Method}

This study used a quantitative approach with independent variables, namely maternal education, income level, maternal posture, and exclusive breastfeeding and the dependent variable was stunting in children under five.

The population was parents with stunted children aged 3-5 years in Demak district, Central Java, Indonesia. The sampling technique used in this study was purposive sampling, in which the sample was taken based on the need to achieve the objectives of this study. The sample of this research is 36 parents with stunted children aged 3-5 years who live in Donorejo village and Tlogoboyo village, Demak district. These areas high population in stunting.

The inclusion criteria in this study were mothers with stunted children aged 3 to 5 years who lived in these areas. The exclusion criteria in this study were mothers with stunted children aged 3 to 5 years who lived in these areas but were not willing to be involved in all study procedures. Enumerators measured stunted children based on standardized calculation formulas of actual measurement data of weight and height. Understanding personal feelings of fear and insecurity of the sample during the Covid-19 pandemic, there is a lack of numerous participants in this research.

The instrument used in this study was a validated questionnaire regarding exclusive breastfeeding, maternal education, and income level as well as a test with a calibrated weighing scale to measure the child's weight according to his age and a stature meter for height that has been calibrated to measure length or height. the child's body according to his age. Besides, these two tools are used to measure the maternal Body Mass Index based on the mother's weight and height. In this study, an in-house survey was conducted, in which the enumerators visited the respondents at home to obtain data.

This research used a cross-sectional study design. The data analysis in this study used a quantitative method. Data analysis used the chi-square test to examine the relationship between maternal education, income level, maternal posture, and exclusive breastfeeding for stunted children.

\section{Result and Discussion}

The study showed that children who were stunted were divided into two categories: $75 \%$ stunted and $25 \%$ severely stunted. The number of stunted boys was greater (53\%) than girls $(47 \%)$. 
Table 1. Children demography status

\begin{tabular}{clc}
\hline \multicolumn{2}{c}{ Status } & n \\
\hline Stunting : & & \\
- & Stunting & $27(75 \%)$ \\
- & Severe Stunting & $9(25 \%)$ \\
\hline Sex : & & \\
- & Boys & $19(53 \%)$ \\
- & Girls & $17(47 \%)$ \\
\hline
\end{tabular}

The results also found that there was no relationship between stunting and maternal education (OR.0,7,95\% CI, 0,132-4,022; $\mathrm{P}=1.000$ ), level of income (OR.0,7;95\% CI, 0,132$4,022 ; \mathrm{P}=1.000)$, maternal posture (OR, 1.0;95\% CI, 0,320-3,123;P=1.000), and exclusive breastfeeding (OR, 1,5;95\%CI,0,469-4,797;P=0,660).

Table 2. Statistical test results on the relationship between maternal education, income level, maternal posture, exclusive breastfeeding, and stunting

\begin{tabular}{|c|c|c|c|c|}
\hline \multirow{2}{*}{ Variable } & \multicolumn{2}{|c|}{ Stunting Status } & \multirow{2}{*}{$\mathbf{p}$} & \multirow{2}{*}{ OR } \\
\hline & Severe Stunting & Stunting & & \\
\hline \multicolumn{5}{|l|}{ Maternal education } \\
\hline Low & 7 & 23 & 1.000 & $0,7(0,132$ to 4,022$)$ \\
\hline Middle & 2 & 4 & & \\
\hline \multicolumn{5}{|l|}{ Income level } \\
\hline Low & 8 & 25 & 1.000 & $0,7(0,132$ to 4,022$)$ \\
\hline Middle & 1 & 2 & & \\
\hline \multicolumn{5}{|l|}{ Maternal posture } \\
\hline Abnormal & 5 & 15 & 1.000 & $1.0(0,320$ to 3,123$)$ \\
\hline Normal & 4 & 12 & & \\
\hline \multicolumn{5}{|l|}{ Exclusive breastfeeding } \\
\hline Never breastfed & 3 & 6 & 0.660 & $1,5(0,469$ to 4,797$)$ \\
\hline Any breastfeeding $>6$ months & 6 & 21 & & \\
\hline
\end{tabular}

Note Low education: Junior High School and below. Middle to High: Senior High School and above. Income level based on Regional Minimum Wages at Demak. Middle Low: Less than IDR 2.432.000. Middle High: More than IDR 2.432.000. The data was analyzed by ChiSquare Statistical Package for The Social Sciences (SPSS). Statistically significant $p \leq 0.05$ and CI $95 \%$.

This study showed that sociodemographic factors, namely maternal education, and income level, were not associated with stunting. Based on the OR value, it can be said that low maternal education may result in severe stunting 0,7 times greater than the middle of maternal education, but it is not significant when seen from the $95 \%$ CI value. The result was the same with the income level. In line with the results of a study conducted in Senegal which proves that there was no relationship between maternal education and income level with stunting, It 
may be explained by the fact that the country's weak health system and health programs contribute to child stunting[12].

The results of the study prove that maternal posture was not related to stunting. Based on the OR value, it can be said that abnormal maternal posture may result in severe stunting 1.0 times greater than normal posture, but it is not significant when seen from the $95 \%$ CI value. This result is different than a study in Mexico which states that short maternal posture is a risk factor for stunted children [13]. Other experts argue that the maternal posture inherits genetically the posture of the child[15].

The results of this study also indicate that stunting was no relationship with exclusive breastfeeding. Based on the OR value, it can be said that non-exclusive breastfeeding may result in severe stunting 1.5 times greater than exclusive breastfeeding, but it is not significant when seen from the $95 \%$ CI value. This result is different than a study in Mexico which states that exclusive breastfeeding is a factor to protect children's health from stunting [13]. The results of other studies in South Sulawesi also stated that there was a link between exclusive breastfeeding and stunting [14]. Experts also suggest that breastfeeding is not optimal during the first month of life can affect the occurrence of stunting [16].

This result is different from previous research. Almost every stunted children in Demak was receiving any breastfeeding for $>6$ months than Mexico and South Sulawesi. Therefore stunting may be caused by several other factors that influence the incidence of stunting in the region. These factors include an unhealthy physical environment such as not available hygiene water and poor sanitation[17][18], which have an impact on the risk of diarrheal diseases and other infectious diseases, causing children to have difficulty eating [13][19], children who are picky eaters [20][21][22] and a less supportive social environment has an impact on the diet of stunted children under five [9][23][24] such as parental diet models[25], maternal knowledge [26][27], unsafe food for consumption [28].

The results of this study indicate that most children under five are stunted rather than severely stunted. In line with the results of a study in India which stated that the prevalence of stunted infants aged 6-8 months in 2015 was $22 \%$ and infants with severe stunting were $10 \%$ [29]. Several studies also showed most stunted children under five were boys than girls[8][15][18][19][28][29]. Another study in Africa also proved that 58\% of boys were stunted and $36 \%$ of girls were stunted (17). This difference is caused by the provision of complementary foods to breastfeeding that is given earlier to boys than girls [29][30] even though the baby's intestines have not been able to digest foods other than breast milk. Besides, the difference in energy needs of boys and girls so that boys need a greater consumption of food. However, in stunted boys, the consumption of these foods is not by the required energy balance. This inhibits the growth and development of the children in the future[29].

\section{Conclusion}

The result of this study showed there was no relationship between stunting and maternal education, income level, maternal posture, exclusive breastfeeding in stunted children in Demak. We recommend to modify the social and physical environment for encouraging healthy life in stunted children.

Acknowledgments. This study was funded by the Budget Implementation List (Daftar Isian Pelaksanaan

Anggaran/DIPA), Sports

Science Faculty, Universitas Negeri 
Semarang(UNNES). We would like to thank the head of Public Health Center Bonang 1, Central Java, Indonesia, for all participants in this research. This article was approved by the Health Research Ethics Committee (HREC), Universitas Negeri Semarang.

\section{References}

[1] Kementerian Kesehatan Republik Indonesia, "Riskesdas 2018."

[2] K. Berhe, O. Seid, Y. Gebremariam, A. Berhe, and N. Etsay, "Risk factors of stunting ( chronic undernutrition ) of children aged 6 to 24 months in Mekelle City , Tigray Region , North Ethiopia : An unmatched case-control study," PLOSONE, pp. 1-11, 2019.

[3] World Health Organization, "WHA Global Nutrition Targets 2025 : Stunting Policy Brief," 2018.

[4] Kementerian Koordinator Bidang Pembangunan Manusia dan Kebudayaan Republik Indonesia, "Penanganan Stunting Terintegrasi Beban Ganda Permasalahan Gizi di Indonesia," Jakarta, 2018.

[5] Tim Nasional Penanggulangan Kemiskinan Republik Indonesia, "100 Kabupaten/Kota Priorias untuk Intervensi Anak Kerdil (Stunting),” Jakarta, 2017. [Online]. Available: http://www.tnp2k.go.id/images/uploads/downloads/Binder Volume1.pdf.

[6] Bidang Pemerintahan dan Sosial dan Budaya Bappeda Litbang Demak, "Sosialisasi Pencegahan Stunting Kabupaten Demak,” Bappeda Litbang Kabupaten Demak, Demak, Sep. 2019.

[7] Kementerian Kesehatan Republik Indonesia, "Buletin Stunting," Kementeri. Kesehat. Republik Indones., vol. 301, no. 5, pp. 1163-1178, 2018.

[8] E. Agedew and T. Chane, "Prevalence of Stunting among Children Aged 6-23 Months in Kemba Woreda, Southern Ethiopia: A Community Based Cross-Sectional Study," Adv. Public Heal., vol. 2015, pp. 1-6, 2015, doi: 10.1155/2015/164670.

[9] D. J. Raiten and A. A. Bremer, "Exploring the nutritional ecology of stunting: New approaches to an old problem," Nutrients, vol. 12, no. 2, 2020, doi: 10.3390/nu12020371.

[10] R. A. Utamia, A. Setiawana, and P. Fitriyania, "Identifying causal risk factors for stunting in children under five years of age in South Jakarta, Indonesia," Second Int. Nurs. Sch. Congr. (INSC 2018, vol. 29, no. 52, pp. 606-611, doi: 10.1016/j.enfcli.2019.04.093.

[11] B. Mzumara, P. Bwembya, H. Halwiindi, R. Mugode, and J. Banda, "Factors associated with stunting among children below five years of age in Zambia: Evidence from the 2014 Zambia demographic and health survey," BMC Nutr., vol. 4, no. 1, pp. 1-8, 2018, doi: 10.1186/s40795018-0260-9.

[12] Z. Li, R. Kim, S. Vollmer, and S. V. Subramanian, "Factors Associated With Child Stunting, Wasting, and Underweight in 35 Low- and Middle-Income Countries," JAMA Netw. open, vol. 3, no. 4, p. e203386, 2020, doi: 10.1001/jamanetworkopen.2020.3386.

[13] A. P. Campos, M. Vilar-Compte, and S. S. Hawkins, "Association between breastfeeding and child stunting in Mexico," Ann. Glob. Heal., vol. 86, no. 1, pp. 1-14, 2020, doi: 10.5334/aogh.2836.

[14] A. R. Maliku, G. T. Tulak, and A. S. A. Maja, "The Correlation Between Exclusive Breastfeeding and Stunting Incident In Toddlers In The Bastem Utara Public Health Care," Sorum. Heal. Sci. J., vol. 1, no. 1, pp. 29-36, 2020, [Online]. Available: https://www.usnsj.com/index.php/shsj/indexURL:https://www.usnsj.com/index.php/shsj/article/v iew/1004.

[15] D. Simbolon, D. Suryani, and E. Yorita, "Prediction Model and Scoring System in Prevention and Control of Stunting Problems in Under Five-Year-Olds in Indonesia," J. Kesehat. Masy., vol. 15, no. 2, pp. 160-170, 2019, doi: 10.15294/kemas.v15i2.13415.

[16] P. Vonaesch et al., "Factors associated with stunting in healthy children aged 5 years and less living in Bangui (RCA)," PLoS One, vol. 12, no. 8, 2017, doi: 10.1371/journal.pone.0182363.

[17] H. Torlesse, A. A. Cronin, S. K. Sebayang, and R. Nandy, "Determinants of stunting in Indonesian children : evidence from a cross-sectional survey indicate a prominent role for the 
water , sanitation and hygiene sector in stunting reduction," BMC Public Health, pp. 1-11, 2016, doi: 10.1186/s12889-016-3339-8.

[18] B. T. Woldeamanuel and T. T. Tesfaye, "Risk Factors Associated with Under-Five Stunting, Wasting, and Underweight Based on Ethiopian Demographic Health Survey Datasets in Tigray Region, Ethiopia," J. Nutr. Metab., vol. 2019, 2019, doi: 10.1155/2019/6967170.

[19] B. J. Akombi, K. E. Agho, J. J. Hall, D. Merom, T. Astell-Burt, and A. M. N. Renzaho, "Stunting and severe stunting among children under-5 years in Nigeria: A multilevel analysis," $B M C$ Pediatr., vol. 17, no. 1, 2017, doi: 10.1186/s12887-016-0770-z.

[20] T. M. Samuel, K. Musa-Veloso, M. Ho, C. Venditti, and Y. Shahkhalili-Dulloo, "A Narrative Review of Childhood Picky Eating and Its Relationship to Food Intakes, Nutritional Status, and Growth," Nutrients, vol. 10, pp. 1-30, 2018, doi: 10.3390/nu10121992.

[21] A. E. Khaq, A. Yuniastuti, and S. R. Rahayu, "An Analysis of Picky Eater Towards Growth and Motor Development at Kebasen District Health Centre," Public Heal. Perspect. J., vol. 3, no. 3, pp. 224-230, 2018.

[22] C. M. Taylor, S. M. Wernimont, K. Northstone, and P. M. Emmett, "Picky/fussy eating in children: Review of definitions, assessment, prevalence and dietary intakes," Appetite, vol. 95, no. July, pp. 349-359, 2015, doi: 10.1016/j.appet.2015.07.026.

[23] M. Masrul, "Description of Parenting Patterns on Stunting and Normal Children in the Specific Area Stunting of Pasaman and West Pasaman District, West Sumatra," J. Midwifery, vol. 3, no. 2, p. 153, 2018, doi: 10.25077/jom.3.2.153-160.2018.

[24] J. Walrod et al., "Community factors associated with stunting, overweight and food insecurity: A community-based mixed-method study in four Andean indigenous communities in Ecuador," BMJ Open, vol. 8, no. 7, pp. 1-11, 2018, doi: 10.1136/bmjopen-2017-020760.

[25] Z. Palfreyman, E. Haycraft, and C. Meyer, "Original Article Development of the Parental Modelling of Eating Behaviours Scale ( PARM ): links with food intake among children and their mothers," Matern. Child Nutr., pp. 617-629, 2014, doi: 10.1111/j.1740-8709.2012.00438.x.

[26] A. Nshimyiryo et al., "Risk factors for stunting among children under five years: a crosssectional population-based study in Rwanda using the 2015 Demographic and Health Survey," BMC Public Health, pp. 1-10, 2019.

[27] N. K. A. Mirayanti and I. G. Juanamasta, "Knowledge and attitude of Mothers about Stunting in Banjar Pengukuh Peguyangan Kangin Village Denpasar," J. Ners dan Kebidanan (Journal Ners Midwifery), vol. 7, no. 3, pp. 320-325, 2020, doi: 10.26699/jnk.v7i3.art.p320-325.

[28] S. Fatima, I. Manzoor, A. M. Joya, S. Arif, and S. Qayyum, "Stunting and associated factors in children of less than five years: A hospital-based study," Pakistan J. Med. Sci., vol. 36, no. 3, 2020, doi: 10.12669/pjms.36.3.1370.

[29] A. K. Dhami MV, Ogbo FA, Osuagwu UL, Ugboma Z, "Stunting and severe stunting among infants in India: the role of delayed introduction of complementary foods and community and household factors.," Glob Heal. Action., vol. 12, no. (1), doi: 10.1080/16549716.2019.1638020.

[30] [S. Lestiarini and Y. Sulistyorini, "Perilaku Ibu pada Pemberian Makanan Pendamping ASI (MPASI) di Kelurahan Pegirian,” J. PROMKES, vol. 8, no. 1, p. 1, 2020, doi: 10.20473/jpk.v8.i1.2020.1-11. 